\title{
Effects of global warming on species interactions: editorial comment on the Highlight Article by King and Sebens
}

\author{
Fabio Bulleri $^{1,2}$
}

Received: 6 March 2018 / Accepted: 7 March 2018 / Published online: 15 March 2018

c) Springer-Verlag GmbH Germany, part of Springer Nature 2018

Anthropogenic climate change is among the major threats to biodiversity (Pecl et al. 2017). Concerns over potential consequences on the functioning of ecosystems and their ability to provide goods and services to humans have prompted research in both terrestrial and aquatic systems. Within this context, the potential for climatic stressors to interact among them, as well as with non-climatic stressors (i.e., multiple stressor scenarios), is widely recognized (Crain et al. 2008). In marine environments, a plethora of studies has, thus, assessed how combinations of different climate stressors-in particular, ocean warming and acidificationcan influence species physiology, phenology and behavior (e.g., Byrne et al. 2009; Nowicki et al. 2012; Iniguez et al. 2016; McQueen and Marshall 2017; Preziosi et al. 2017; Davis et al. 2018, to cite a few). Often, climate-induced modifications at the individual level, scale up to that of the community, through the filter of species interactions (Post and Pedersen 2008; Russell et al. 2009; Ockendon et al. 2014). Nonetheless, indirect effects of climate changes have received less attention than direct effects. For instance, only recently species interactions have been incorporated into models aiming to forecast species distribution under future climate scenarios, despite the long-standing view of their role to be relevant only at local scales being amply discredited (Wisz et al. 2013).

By means of a mesocosm experiment, King and Sebens have assessed how air and water warming influences the growth rates of the barnacle Balanus glandula and of the dog whelk Nucella ostrina, as well as whelk predation rates. The

Responsible Editor: U. Sommer.

Fabio Bulleri

fabio.bulleri@unipi.it

1 Dipartimento di Biologia, Università di Pisa, Via Derna 1, 56126 Pisa, Italy

2 CoNISMa, Consorzio Nazionale Interuniversitario per le Scienze del Mare, Piazzale Flaminio 9, 00196 Roma, Italy growth of barnacles increased following the warming of both air and water, while that of whelks decreased in warmer air conditions and was not influenced by water warming. Whelk predation rates decreased by $35 \%$ under warmer air conditions, although these negative effects were, to some extent, mitigated by warmer water. Under these circumstances, benefits of warming for barnacles might be twofold: increased growth and lower predation pressure. It is, therefore, evident that a robust estimate of the effects of warming on this simple prey-predator system requires integration between air and water and between each species performance and their interaction.

As the authors themselves point out, the net effects of water and air warming on the species investigated might be influenced by other factors, such as whelk behavioral responses and air humidity during emersion. Nonetheless, this study provides solid information for generating hypotheses to be tested through more complex experimental setups, possibly including a field component. As impacts of increased climatic variability and extremes on physiological and ecological processes are likely to be as important as increments in average values (Vázquez et al. 2017), the temporal heterogeneity of physical drivers is an important component of climate change that should be formally incorporated into future studies.

\section{References}

Byrne M, Ho M, Selvakumaraswamy P, Nguyen HD, Dworjanyn SA, Davis AR (2009) Temperature, but not $\mathrm{pH}$, compromises sea urchin fertilization and early development under nearfuture climate change scenarios. Proc R Soc Lond B Biol Sci 276:1883-1888

Crain CM, Kroeker K, Halpern BS (2008) Interactive and cumulative effects of multiple human stressors in marine systems. Ecol Lett 11:1304-1315

Davis BE, Flynn EE, Miller NA, Nelson FA, Fangue NA, Todgham AE (2018) Antarctic emerald rockcod have the capacity to compensate for warming when uncoupled from $\mathrm{CO}_{2}$-acidification. Glob Change Biol 24:655-670 
Iniguez C, Carmona R, Lorenzo MR, Niell FX, Wiencke C, Gordillo FJL (2016) Increased temperature, rather than elevated $\mathrm{CO}_{2}$, modulates the carbon assimilation of the Arctic kelps Saccharina latissima and Laminaria solidungula. Mar Biol 163:248

McQueen K, Marshall CT (2017) Shifts in spawning phenology of cod linked to rising sea temperatures. ICES J Mar Sci 74:1561-1573

Nowicki JP, Miller GM, Munday PL (2012) Interactive effects of elevated temperature and $\mathrm{CO}_{2}$ on foraging behavior of juvenile coral reef fish. J Exp Mar Biol Ecol 412:46-51

Ockendon N, Baker DJ, Carr JA, White EC, Almond REA, Amano T, Bertram E, Bradbury RB, Bradley C, Butchart SHM, Doswald N, Foden W, Gill DJC, Green RE, Sutherland WJ, Tanner EVJ, Pearce-Higgins JW (2014) Mechanisms underpinning climatic impacts on natural populations: altered species interactions are more important than direct effects. Glob Change Biol 20:2221-2229

Pecl GT, Araújo MB, Bell JD, Blanchard J, Bonebrake TC, Chen I-C, Clark TD, Colwell RK, Danielsen F, Evengård B, Falconi L, Ferrier S, Frusher S, Garcia RA, Griffis RB, Hobday AJ, Janion-Scheepers C, Jarzyna MA, Jennings S, Lenoir J, Linnetved HI, Martin VY, McCormack PC, McDonald J, Mitchell NJ, Mustonen T, Pandolfi JM, Pettorelli N, Popova E, Robinson SA, Scheffers BR, Shaw JD, Sorte CJB, Strugnell JM, Sunday JM, Tuanmu M-N, Vergés A, Villanueva C, Wernberg T, Wapstra E,
Williams SE (2017) Biodiversity redistribution under climate change: impacts on ecosystems and human well-being. Science 355:aai9214

Post E, Pedersen C (2008) Opposing plant community responses to warming with and without herbivores. Proc Natl Acad Sci USA 105:12353-12358

Preziosi BM, Runge JA, Christensen JP, Jones RJ (2017) Effects of pH and temperature on egg hatching success of the marine planktonic copepod, Calanus finmarchicus. Mar Biol 164:218

Russell BD, Thompson JAI, Falkenberg LJ, Connell SD (2009) Synergistic effects of climate change and local stressors: $\mathrm{CO}_{2}$ and nutrient-driven change in subtidal rocky habitats. Glob Change Biol 15:2153-2162

Vázquez DP, Gianoli E, Morris WF, Bozinovic F (2017) Ecological and evolutionary impacts of changing climatic variability. Biol Rev 92:22-42

Wisz MS, Pottier J, Kissling WD, Pellissier L, Lenoir J, Damgaard CF, Dormann CF, Forchhammer MC, Grytnes J-A, Guisan A, Heikkinen RK, Høye TT, Kühn I, Luoto M, Maiorano L, Nilsson M-C, Normand S, Öckinger E, Schmidt NM, Termansen M, Timmermann A, Wardle DA, Aastrup P, Svenning J-C (2013) The role of biotic interactions in shaping distributions and realised assemblages of species: implications for species distribution modelling. Biol Rev 88:15-30 